\title{
Doğu Akdeniz'deki Tsunamijenik Depremlerin Sosyal Risklerinin Monte Carlo Yöntemi Değerlendirmesi
}

\author{
Cüneyt YAVUZ ${ }^{1}$ \\ Elçin KENTEL ${ }^{2}$
}

\section{ÖZ}

Bu çalışmada tarihdeki büyük depremlere benzer bir tsunamijenik depremin Türkiye'nin Doğu Akdeniz kıyısında yer alan kritik bölgelerde yaratacağı olası sosyal riskler analiz edilmiştir. Deprem kaynağı olarak 365 Girit, 1222 Paphos ve 1303 Girit depremlerinden yararlanılarak Monte Carlo yöntemi ile rastgele depremler oluşturulmuş ve Nami-Dance yazılımı kullanılarak deprem kaynaklı tsunamiler modellenmiştir. Türkiye'nin Doğu Akdeniz kıyısında bulunan yerleşim yerleri, tarım alanları, limanlar ve havaalanları gibi kritik bölgeler için tsunami dalga yükseklikleri ve bağıl sosyal risk seviyeleri hesaplanmıştır. Alanya Kıyı Şeridi ve Çukurova Tarım Alanı'ndaki bağıl sosyal riskler her üç deprem lokasyonu için de "Çok Yüksek Sosyal Risk” seviyesinde çıkmıştır. Bu çalışmanın sonuçları ileride yaşanması muhtemel deprem kaynaklı bir tsunamiden korunabilmek için alınacak tedbirlerin belirlenmesi açısından yerel otoriteler ve kamu kurumlarına bilimsel bir kaynak olacaktır.

Anahtar Kelimeler: Tsunamijenik depremler, monte carlo simulasyonu, sosyal risk analizi.

\section{ABSTRACT \\ Social Risk Evaluation of Tsunamigenic Earthquakes using Monte Carlo Simulations in the Eastern Mediterranean Sea}

A comprehensive social risk analysis is performed in this study to evaluate probable social risks due to a tsunamigenic earthquake similar to the great earthquakes in history. Using 365 Crete, 1222 Paphos and 1303 Crete earthquake locations as earthquake sources, random earthquakes were created with Monte Carlo method and earthquake-triggered tsunamis are modeled using Nami-Dance software. Inundations and relative social risk levels are calculated for each selected critical region such as city centers, agricultural areas, ports, and

\footnotetext{
Not: Bu yazı

- Yayın Kurulu’na 13 Kasım 2020 günü ulaşmıştır. 13 Ağustos 2021 günü yayımlanmak üzere kabul edilmiştir.

- 31 Ocak 2023 gününe kadar tartışmaya açıktır.

- https://doi.org/10.18400/tekderg.825393
}

1 Kütahya Dumlupınar Üniversitesi, Teknik Bilimler MYO, İnşaat Teknolojisi Bölümü, Kütahya cuneyt.yavuz@dpu.edu.tr - https://orcid.org/0000-0001-9767-7234

2 Orta Doğu Teknik Üniversitesi, İnşaat Mühendisliği Bölümü, Ankara ekentel@metu.edu.tr - https://orcid.org/0000-0002-7477-0345 
airports located at the Turkish Eastern Mediterranean coastline. Alanya Coastline and Cukurova Agricultural Area are evaluated to have "Extreme Risk Level" according to the relative social risk assessment studies for all tsunamigenic earthquake location. The results of this study will be a reliable scientific source for the local and governmental authorities in planning necessary precautions against a probable tsunami event.

Keywords: Tsunamigenic earthquakes, monte carlo simulation, social risk analysis.

\section{GİRiş}

Faylar yeryüzü kabuğu üzerinde bulunan hatta göz ile görülebilinen kırık kısımlardır [1]. Bazı faylar dünya yüzeyinde gözle görünür kırıklar oluşturur, bazıları oluşturmaz. Son 10000 yılda yeryüzünde kırık oluşturan faylar aktif fay olarak isimlendirilir. Diğer kısım faylar ise kör faylardır [2]. Dünya kabuğunda göz ile görülen fay hatlarına en iyi örneklerden biri “Ateş Çemberi” olarak ifade edilen Pasifik Okyanusu tabanında bulunan fay hattıdır (Fotoğraf 1).

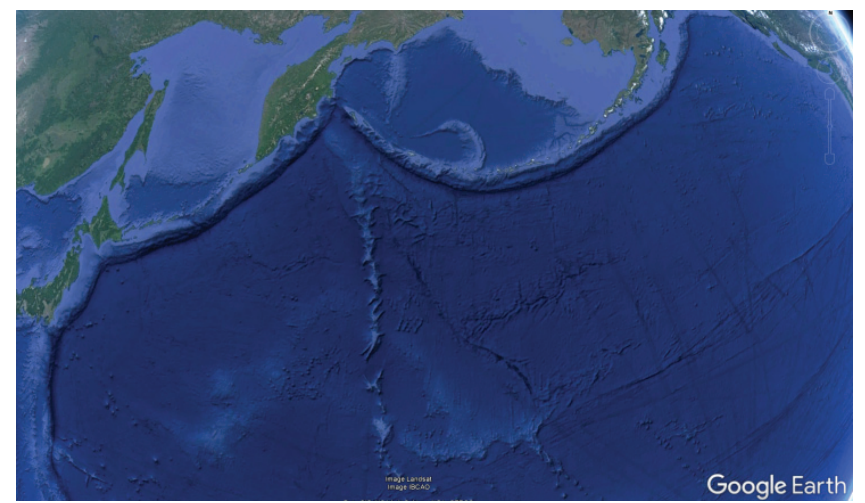

Fotoğraf 1 - “Ateş çemberi” ile isimlendirilen Pasifik fay hattı [3]

Bütün depremler tsunami oluşturmazlar. Tsunami oluşması için en önemli kriter, deniz tabanında veya topoğrafyasında oluşan ani değişimlerdir. Deniz içerisinde oluşan depremler, volkanik aktiviteler, toprak kayması, buzul kırılmaları, ve meteor düşmesi gibi nedenler tsunamileri oluşturan başlıca etmenlerdir. En büyük tsunamiler fay hatlarının dalma-batma zonlarında oluşan depremlerden sonra gözlemlenir. Tektonik plakaların çarpışma bölgelerinde meydana gelen yüksek sismik aktiviteler, deniz tabanına yakın bölgelerde yıkıcı depremler oluşmasına neden olur. Plakalar birbirlerine doğru kayarken, deniz tabanında binlerce kilometreyi bulan alanda yer değiştirmeler oluşturur [4]. Deniz tabanında deprem kaynaklı bir atım oluştuğunda, atım üzerinde bulunan tüm su tabakasına büyük bir enerji aktarımı gerçekleşir. Bu enerji deniz yüzeyinde su seviyesinin yükselmesine (tsunami) ve yayılmasına neden olur. Derin denizde tsunami dalgalarının yüksekliği birkaç santimetre olabilirken hızı su derinliği ve yerçekiminin bir fonksiyonu olarak $V=\sqrt{g h}$ formülü ile hesaplanır. Kıyıya yaklaştıkça dalgaların hızı azalır fakat bu durumda dalga yükseklikleri artar ve metrelerce yükseklikteki dalgalar büyük bir enerji ile kıyı şeridine önemli ölçüde zarar verebilir. Geçmişten günümüze kadar meydana gelen tsunami olayları, kıyı şeridinde 
yaşayan insanların ölümüne, tarım alanlarının yok olmasına ve kıyıda yapılmış bir çok önemli yapının zarar görmesine neden olmuştur.

Çizelge 1 - Bu çalışmada kullanılan deprem parametreleri ve tanımları [8]

\begin{tabular}{|c|c|c|c|c|}
\hline Parametre & Açıklama & $\begin{array}{l}\text { Nami- } \\
\text { Dance } \\
\text { Girdisi }\end{array}$ & $\begin{array}{c}\text { Bağımlı } \\
\text { Parametre } \\
\text { mi? }\end{array}$ & $\begin{array}{c}\text { Depremden } \\
\text { Depreme } \\
\text { Değişim }\end{array}$ \\
\hline Batimetri & $\begin{array}{c}\text { Deprem ve tsunami } \\
\text { simülasyonu için seçilen } \\
\text { bölge }\end{array}$ & Evet & Hayır & Hayır \\
\hline $\begin{array}{c}\text { Izgara } \\
\text { Büyüklüğ̈̈̈ }\end{array}$ & Batimetriye bağlı & Evet & Hayır & Hayır \\
\hline $\begin{array}{c}\text { Deprem } \\
\text { Büyüklüğ̈̈u } \\
\left(M_{w}\right)\end{array}$ & $\begin{array}{l}\text { Sismik momentin bir } \\
\text { fonksiyonu }\end{array}$ & Evet & Hayır & Evet \\
\hline Fokal Derinlik & $\begin{array}{l}\text { Deprem iç merkezini } \\
\text { (hypocenter) ifade eder. } \\
\text { İçmerkez ise kabuk } \\
\text { kısmında kırılmanın } \\
\text { başladığı Hayırttadır. }\end{array}$ & Evet & Hayır & Evet \\
\hline Boylam & \multirow{2}{*}{ Kırılan bölgenin lokasyonu } & Evet & Evet & Evet \\
\hline Enlem & & Evet & Evet & Evet \\
\hline Doğrultu Açısı & $\begin{array}{l}\text { Fayın kuzey yönüne göre } \\
\text { açısı }\end{array}$ & Evet & Evet & $\begin{array}{c}\text { Fayın } \\
\text { lokasyonuna } \\
\text { bağlı }\end{array}$ \\
\hline Dalma Açısı & $\begin{array}{c}\text { Kırığın yatay düzleme göre } \\
\text { açısı }\end{array}$ & Evet & Evet & Hayır \\
\hline Eğim Açısı & $\begin{array}{c}\text { Kırılma anında fayın } \\
\text { hareket eden parçasının fay } \\
\text { doğrultusuna olan açısı }\end{array}$ & Evet & Evet & $\begin{array}{l}\text { Fayın türüne } \\
\text { bağlı }\end{array}$ \\
\hline Atım Miktarı & $\begin{array}{l}\text { Fayın önceden belirlenen } \\
\text { referans Hayırktasından } \\
\text { olan yer değiştirme oranı }\end{array}$ & Evet & Evet & $\begin{array}{l}\text { Depremin } \\
\text { büyüklüğüne } \\
\text { bağlı }\end{array}$ \\
\hline $\begin{array}{c}\text { Sismik } \\
\text { Moment }\left(M_{0}\right)\end{array}$ & $\begin{array}{l}\text { Kayma modülü, fay } \\
\text { uzunluğu, fay genişliği ve } \\
\text { atım miktarının bir } \\
\text { fonksiyonu }\end{array}$ & Hayır & Evet & Evet \\
\hline $\begin{array}{c}\text { Fay Uzunluğu } \\
(L)\end{array}$ & & Evet & Evet & Evet \\
\hline $\begin{array}{c}\text { Fay Genişliği } \\
(W)\end{array}$ & & Evet & Evet & Evet \\
\hline
\end{tabular}


Akdeniz $3900 \mathrm{~km}$ uzunluğu, $1600 \mathrm{~km}$ maksimum genişliği ve $4400 \mathrm{~m}$ ye varan su derinliği ile dünya üzerindeki iç denizlerin en büyüklerinden biridir. Doğu Akdeniz'de günümüzde bile yüksek sismik aktivitenin gözlendiği Helenik ve Kıbrıs batma-dalma zonları bulunmaktadır. Son 3000 yılda bu fay hatları üzerinde oluşan depremlerin bir sonucu olarak en az 96 tsunami olayı kayıtlara geçmiştir [5]. Doğu Akdeniz kıyıları tarih boyunca birçok medeniyetin beşiği olmuştur ve antik dünyanın yedi harikasından dördü Akdeniz kıyı şeridinde inşa edilmiştir. Akdeniz kıyılarında pek çok antik kent insanlık tarafından inşa edilmiş ve başta depremler ve tsunamiler olmak üzere doğal afetler nedeniyle harap olmuştur. Son yıllarda Türkiye'nin Akdeniz sahilleri büyük ticari limanlar, hava limanları, petroldoğalgaz boru hatları ve enerji tesisleri ile yoğun bir şekilde kullanılmaya başlanmıştır [6]. $\mathrm{Bu}$ bölgede olası yeni bir tsunamijenik depremin yaşanması durumunda günümüz koşullarında Türkiye'nin Doğu Akdeniz kıyılarında bulunan kritik bölgelerde oluşacak sosyal risk seviyelerinin detaylı araştırmaları ve değerlendirmeleri bulunmamaktadır.

Bu çalışmada, ODTÜ İnşaat Mühendisliği Bölümü Kıyı ve Liman Laboratuvarı tarafından geliştirilen Nami-Dance tsunami simülasyon programı kullanılmıştır [7]. Birleşik Devletler Jeolojik Araştırma Enstitüsü (USGS) deprem parametrelerinin tanımlarından oluşan kapsamlı bir deprem sözlüğü oluşturmuştur [8]. Deprem simülasyonları için gereken parametreler ve bu parametrelerin USGS tarafından hazırlanmış olan tanımları Çizelge 1'de verilmiştir. Bu çalışmada kaynak olarak kullanılan 365 Girit, 1222 Paphos ve 1303 Girit depremlerinin enlem ve boylamları, doğrultu, dalma ve eğim açıları literatürden elde edilmiştir. Deprem büyüklüğü $\left(M_{w}\right)$ ve Fokal derinlik ise her bir Monte Carlo simulasyonunda bu değişkenleri temsil eden olasılık dağılımlarından rastgele seçilmiştir.

\section{TEORIK METOT}

Türkiye'nin Doğu Akdeniz sahillerinde bulunan yerleşim yerleri, tarım alanları, limanları ve havaalanlarının olası bir tsunami tehlikesi durumunda sosyal risk seviyelerinin nasıl hesaplanacağı konusundaki iş akış şeması Çizim 1'de verilmiştir.

Bu çalışmada, üç farklı lokasyon için - 365 Girit, 1222 Paphos ve 1303 Girit depremlerinin lokasyonları - Monte Carlo yöntemi ile probabilistic tsunami simulasyonları gerçekleştirilmiştir. Her bir tarihsel deprem lokasyonunda Monte Carlo yöntemi kullanılarak farklı büyüklük ve fokal derinliğe sahip 1000'er rastgele deprem kaynağı oluşturulmuş ve olası deprem kaynaklı tsunamilerin Nami Dance Programı kullanılarak simulasyonları yapılmıştır. Simulasyon sonucunda elde edilen tsunami dalgalarından kaynaklı su basma seviyeleri ve seçilen kritik bölgelerdeki kişi sayısı dikkate alınarak da sosyal risk analizi yapılmıştır.

\section{1. Çalışma Alanı}

Doğu Akdeniz Alp-Himalaya kıta kabuğunun içerisinde yer almaktadır. Bu bölgede dünyada olan depremlerin 15\% oluşmaktadır [9]. Bu bölgedeki insanlar tarih boyunca Helenik ve Kıbrıs fayları üzerinde olmuş birçok yıkıcı deprem ve tsunamiler yaşamışlardır. Son 3 bin yılda Doğu Akdeniz'de 90 nın üzerinde tsunami olayı kayıtlara geçmiştir [911]. Bu da ortalama her 30 yılda bir tsunami olayının görülme ihtimali olduğunu ve bölgenin aktif sismik yapısını gözler önüne sermektedir. Doğu Akdeniz çalışma alanı Fotoğraf 2'de 
verilmiştir. Çalışma kapsamında seçilen toplam 32 adet kritik bölge, koordinatları, risk analizinde kullanılan alanları ve literatürden elde edilen nüfus yoğunlukları [12] Çizelge 2'de verilmiştir.

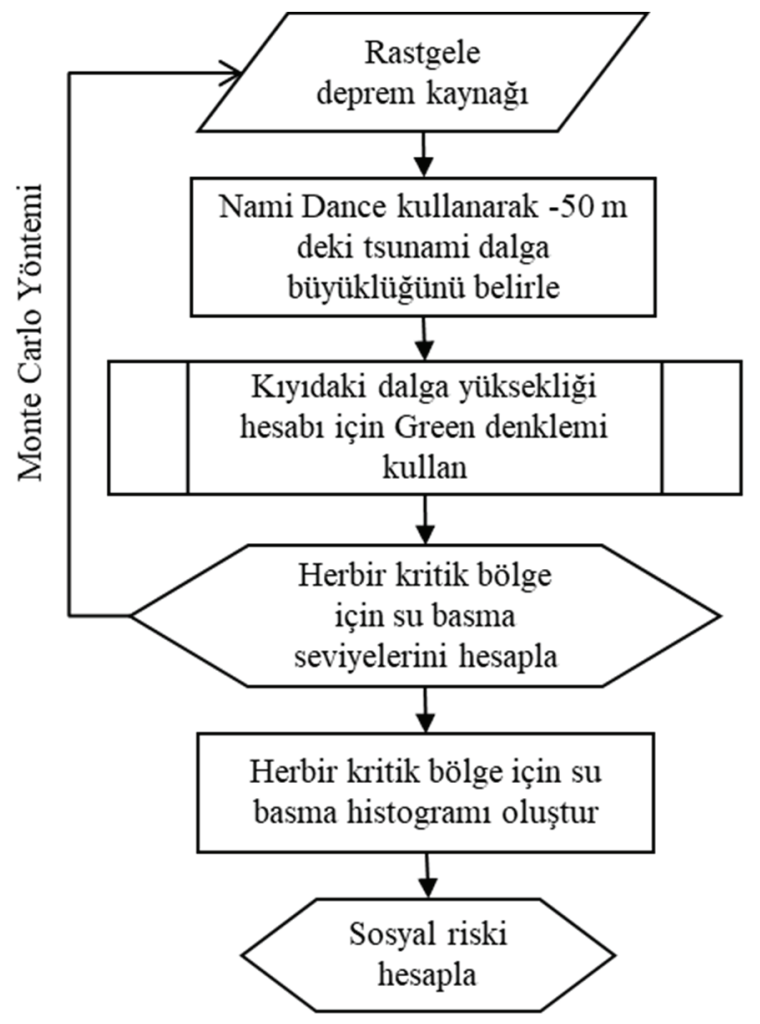

Çizim 1 - Bu çalışmada kullanılan sosyal risk analizi adımları

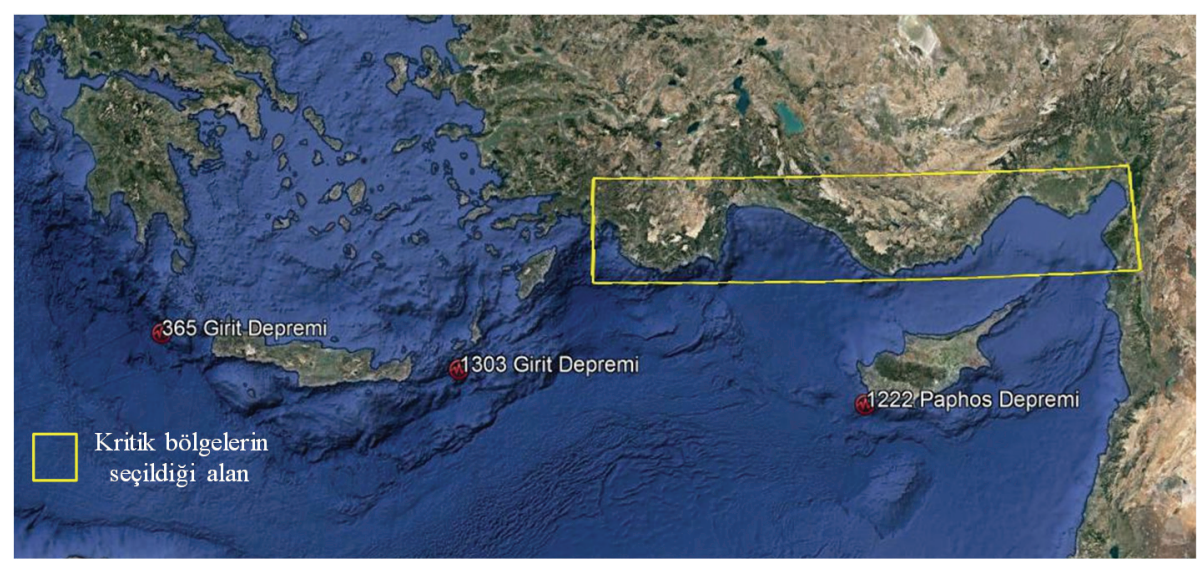

Fotoğraf 2 - Çalışma alanı [3] 
Doğu Akdeniz'deki Tsunamijenik Depremlerin Sosyal Risklerinin Monte Carlo ...

Çizelge 2 - Çalışma alanında seçilmişs olan kritik bölgeler

\begin{tabular}{|c|c|c|c|c|c|}
\hline \multirow{2}{*}{ Kritik Bölge } & \multirow{2}{*}{ İl } & \multicolumn{2}{|c|}{ Koordinatlar } & \multirow{2}{*}{$\begin{array}{c}\text { Yaklaşı1k } \\
\text { Alan }\left(\mathrm{km}^{2}\right)\end{array}$} & \multirow{2}{*}{$\begin{array}{c}\text { Nüfus } \\
\text { yoğunluğu [12] } \\
\underset{\left(\mathrm{kişi} / \mathrm{km}^{2}\right)}{ }\end{array}$} \\
\hline & & Enlem & Boylam & & \\
\hline Akdeniz Tatil Köyleri & Antalya & 36.39 & 34.25 & 8.22 & 270 \\
\hline Alanya Kıyı Şeridi & Antalya & 36.32 & 32.02 & 10.78 & 186 \\
\hline Anamur Kıyı Şeridi & Mersin & 36.03 & 32.51 & 2.49 & 49 \\
\hline Antalya Konyaalti & Antalya & 36.51 & 30.37 & 10.70 & 300 \\
\hline Arsuz Tatil Köyleri & Hatay & 36.25 & 35.54 & 4.66 & 104 \\
\hline Belek Tatil Köyleri & Antalya & 36.51 & 31.03 & 27.25 & 4548 \\
\hline Dalaman Şehir Merkezi & Muğla & 36.46 & 28.48 & 7.79 & 60 \\
\hline Demre Şehir Merkezi & Antalya & 36.14 & 29.59 & 15.59 & 55 \\
\hline Erdemli Şehir Merkezi & Mersin & 36.36 & 34.18 & 3.56 & 65 \\
\hline Fethiye Şehir Merkezi & Muğla & 36.39 & 29.07 & 12.83 & 50 \\
\hline Finike Şehir Merkezi & Antalya & 36.17 & 30.08 & 3.39 & 73 \\
\hline İskenderun Şehir Merkezi & Hatay & 36.34 & 36.1 & 15.84 & 999 \\
\hline Kazanlı Şehir Merkezi & Mersin & 36.48 & 34.45 & 1.04 & 65 \\
\hline Kemer Şehir Merkezi & Antalya & 36.36 & 30.33 & 2.44 & 102 \\
\hline Kızkalesi Tatil Köyleri & Mersin & 36.27 & 34.08 & 0.69 & 14 \\
\hline Manavgat Kıyı Şeridi & Antalya & 36.46 & 31.23 & 25.24 & 98 \\
\hline Mersin Şehir Merkezi & Mersin & 36.47 & 34.37 & 19.02 & 114 \\
\hline Samandağ Şehir Merkezi & Hatay & 36.05 & 35.58 & 4.30 & 267 \\
\hline Sarıseki Şehir Merkezi & Hatay & 36.4 & 36.13 & 1.16 & 100 \\
\hline Susanoğlu Tatil Köyleri & Mersin & 36.22 & 34.08 & 8.32 & 400 \\
\hline Taşucu Şehir Merkezi & Mersin & 36.19 & 33.53 & 7.25 & 45 \\
\hline Türkler Tatil Köyleri & Antalya & 36.36 & 31.49 & 7.60 & 4044 \\
\hline Yemişkumu Tatil Köyleri & Mersin & 36.29 & 34.1 & 0.19 & 1557 \\
\hline Dalaman Havaalanı & Muğla & 36.42 & 28.47 & 6.43 & 10112 \\
\hline İskenderun Limanı & Hatay & 36.35 & 36.11 & 3.79 & 137 \\
\hline Mersin Limanı & Mersin & 36.48 & 34.39 & 4.93 & 1410 \\
\hline MMK Metalurji Limanı & Hatay & 36.46 & 36.12 & 0.64 & 4314 \\
\hline Akdeniz Limanı & Antalya & 36.5 & 30.36 & 2.25 & 1198 \\
\hline Tirtar Yat Limanı & Mersin & 36.31 & 34.13 & 0.15 & 278 \\
\hline Çukurova Tarım Alanı & Adana & 36.45 & 35.14 & 2306 & 1 (kişi/ha) \\
\hline Dalaman Tarım Alanı & Muğla & 36.46 & 28.48 & 80 & 7 (kişi/ha) \\
\hline Samandag Tarım Alanı & Hatay & 36.03 & 35.58 & 19 & 3 (kişi/ha) \\
\hline
\end{tabular}




\subsection{Monte Carlo Yöntemi ile Tsunami Analizi}

Monte Carlo yönteminde değerleri ilgili olasılık dağılımından rastgele seçilen parametrenin bağımsız parametreler olmaları esastır. Doğu Akdeniz'de Helenik ve Kıbrıs fayları üzerinde oluşmuş tarihsel depremlerin $M_{\mathrm{w}}$ ve Fokal derinlik değerleri dikkate alınarak bu iki bağımsız değişken için olasılık yoğunluk fonksiyonları oluşturulmuştur. $M_{\mathrm{w}}$ ve Fokal derinlik için oluşturulan olasılık yoğunluk fonksiyonlarına uygun dağılımlar seçilmiş ve uygunluk derecesi Kolmogorov-Smirnov yöntemi ile test edilmiştir [13]. Güvenilir bir risk analizi yapabilmek için gereken Monte Carlo simulasyon sayısı için Yavuz vd. [13] tarafından yapılan bir çalışma sonucunda yaklaşık 1000 civarında sümulasyonun güvenilir bir risk analizi için yeterli olduğu gösterilmiştir (Çizim 2). Dolayısıyla her bir kaynak için (365 Girit, 1222 Paphos ve 1303 Girit lokasyonları) belirlenen dağılımlardan 1000 'er adet rastgele deprem verisi üretilmiştir. Deprem kaynağının tanımlanabilmesi için gerekli diğer bağımlı parametreler (doğrultu, eğim ve dalma açıları, enlem ve boylam) literatürden elde edilmiştir (Çizelge 3) [9-11]. Daha sonra, Nami-Dance programı kullanılarak rasgele depremlerden kaynaklı oluşan tsunamiler modellenmiştir.

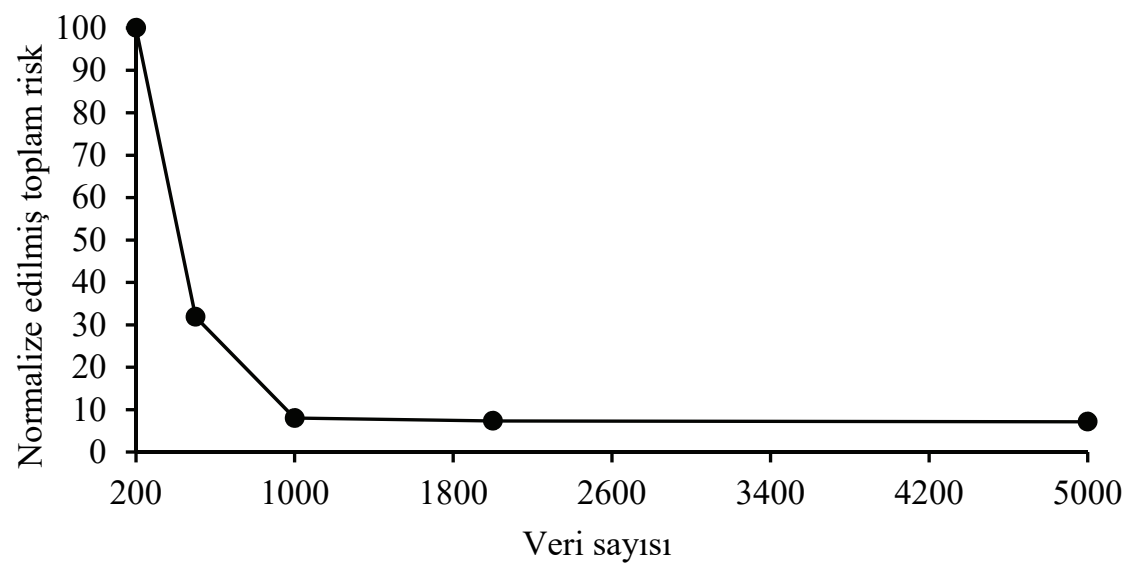

Çizim 2 - Normalize edilmiş toplam riskin veri sayısı ile değişimi [13]

Çizelge 3 - 365 Girit, 1222 Paphos ve 1303 Girit için bağımlı deprem parametreleri [9-11]

\begin{tabular}{cccc}
\hline $\begin{array}{c}\text { Bağımlı deprem } \\
\text { parametreleri }\end{array}$ & 365 Girit Depremi & $\begin{array}{c}\text { 1222 Paphos } \\
\text { Depremi }\end{array}$ & $\begin{array}{c}1303 \text { Girit } \\
\text { Depremi }\end{array}$ \\
\hline Boylam & $24^{\circ} 48^{\prime} 00^{\prime \prime}$ & $32^{\circ} 36^{\prime} 00^{\prime \prime}$ & $27^{\circ} 00^{\prime} 00^{\prime \prime}$ \\
Enlem & $35^{\circ} 14^{\prime} 00^{\prime \prime}$ & $34^{\circ} 42^{\prime} 00^{\prime \prime}$ & $35^{\circ} 00^{\prime} 00^{\prime \prime}$ \\
Doğrultu açısı $\left(^{\circ}\right)$ & 295 & 305 & 115 \\
Dalma açısı $\left(^{\circ}\right)$ & 15 & 35 & 45 \\
Eğim açısı $\left(^{\circ}\right)$ & 90 & 110 & 110 \\
\hline
\end{tabular}




\subsection{Deprem Parametrelerinin Hesaplanması}

Nami-Dance simülasyon programında kullanılacak deprem verileri Çizelge 1'de verilmiştir. Çizelge 3 'te verilen bağımlı parametreler için doğrudan ilgili depremin literatürde verilen değerleri alınmıştır. Ayrıca her bir tarihsel deprem için 1000'er adet rastgele seçilen $M_{\mathrm{w}}$ ve Fokal derinlik parametreleri Monte Carlo simulasyonlarında kullanılmıştır. $M_{\mathrm{w}}$ ye bağlı olan diğer deprem parametreleri literatürde yaygın bir şekilde kullanılan ampirik formüller kullanılarak hesaplanmıştır.

Hanks ve Kanamori [14] $M_{0}$ nun Çizelge 1'de verilen deprem parametreleri ile depremin büyüklüğünün bir ifadesi olduğunu göstermiştir (Eş. 1).

$M_{0}=\mu L W D$

burada $\mu$ kabuğun kayma modülü (malzemenin türüne bağlı), $L$ fay uzunluğu, $W$ fay genişliği, ve $D$ atım miktarıdır.

$M_{w}$ ve $M_{0}$ arasındaki ilişkiyi gösteren ampirik eşitlik ise [14]:

$M_{w}=2 / 3 \log \left(M_{0}\right)-10.7$

Hanks ve Kanamori [14] tarafından ortaya konan bu iki eşitlik ile deprem parametreleri hesaplanabilse de $M_{0}$ eşitliğindeki parametreler arasındaki nitel farklılığın belirsizliği ve deprem kataloglarında kırılan alanın net olarak belirlenememesi özellikle atım miktarlarının yanlış yorumlanmasına neden olmaktadır. Örneğin $L$ ve $W$ değerleri küçük tutularak $D$ değeri yükseltilmekte ve benzer deprem büyüklükleri için farklı atım miktarları hesaplanabilmektedir. Bu belirsizliği çözmek adına, $M_{w^{-}} L$, ve $M_{w^{-}}-W$ arasındaki ilişkiyi belirlemek için farklı çalışmalar incelenmiş ve Çizim 3'te bu çalışmalardaki bulgular aynı deprem büyüklükleri dikkate alınarak gösterilmiştir. Çizim 3'te farklı bilim insanlarının $M_{w^{-}}$ $L$, ve $M_{w}-W$ arasındaki ilişkiyi belirlemek için önermiş oldukları eşitlikler aynı deprem verisi üzerine işlenmiş ve aşağıdaki eğriler elde edilmiştir.
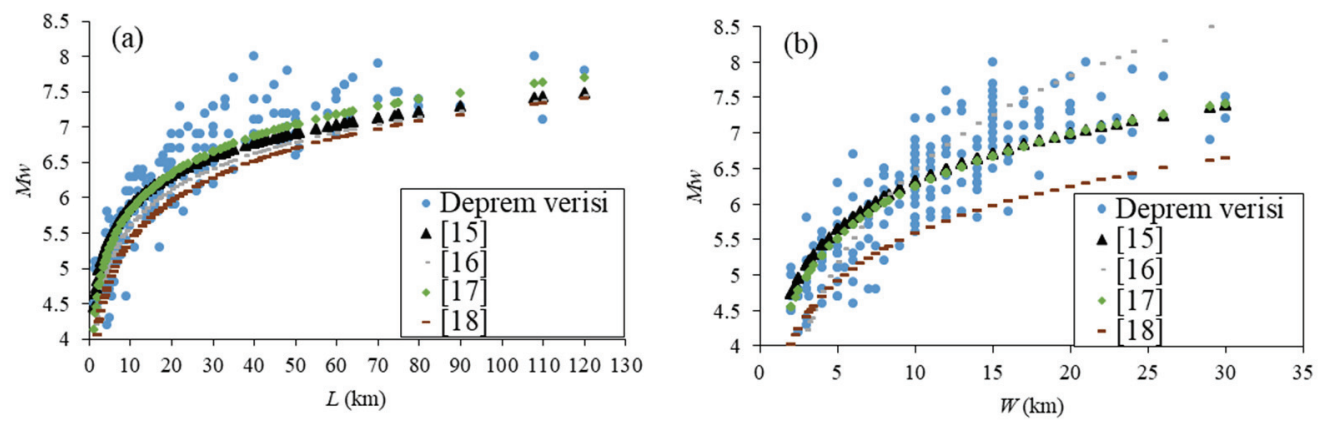

Çizim 3 - Farklı bilimsel kaynaklara göre (a) $M_{w^{-}}$L ve (b) $M_{w^{-}}$W ilişkileri [13] 
İncelenen çalışmalar Wells ve Coppersmith [15] tarafindan önerilen ve regresyon analizleri ile desteklenen eşitliklerin $M_{w}-L$, ve $M_{w}-W$ arasındaki ilişkiyi en uygun şekilde ortaya koyduğunu göstermektedir. Buna göre:

$M_{w}=4.38+1.49 \log (L)$

$M_{w}=4.06+2.25 \log (W)$

eşitlikleri bu çalışmada $L$ ve $W$ nin belirlenmesi için kullanılmıştır. Daha sonra $D$ Eş.1 kullanılarak belirlenmiş̧tir. Bu şekilde deprem parametrelerinin herhangi bir yolla yanlış yorumlanıp karmaşık sonuçların çıkmaması sağlanmıştır.

\subsection{Tsunami Simülasyonları ve Su Basma Seviyelerinin Hesaplanması}

Türkiye'nin Akdeniz sahilleri çok uzun ve çalışma alanı çok büyük olduğu için kıyı şeridinin ve sahil kısımlarının yüksek çözünürlüklü haritaların elde edilme şansı bulunmamaktadır. Bu durum simülasyon sonucunda $0 \mathrm{~m}$ deniz seviyesinde tsunami dalga yüksekliğinin doğru bir şekilde hesaplanamamasına neden olmaktadır. Her bir kritik bölge için dalga yükseklikleri $50 \mathrm{~m}$ açığa dijital bir ölçek tanımlanıp, bu ölçekten elde edilen dalga yüksekliğinin Green eşitliği kullanılarak -1 m seviyesine taşınması ile çözülmüştür. Bu çalışmada tsunami değerlendirmesi, yayılımı ve su basmaların simüle edebilen bir kapasiteye sahip olan ve ODTÜ İnşaat Mühendisliği Bölümü Kıyı ve Liman Laboravuvarı öğretim üyelerinin katkılarıyla geliştirilen Nami-Dance programı kullanılmışıtır. kullanılmıştır. Nami Dance yazılımı deprem girdilerine dayanarak bir deprem ve tsunami kaynağı oluşturmaktadır. Nami-Dance, deniz yüzeyi ve deniz tabanı topoğrafyasının sınır koşullarını oluşturduğu doğrusal olmayan sığ su denklemleri kullanır [7]. Global bir kütlenin korunumu denkleminin dikkate alınarak derivasyonları yapılan sığ su denklemleri uzun dalga varsayımı ile tsunami yayılım koşullarını büyük bir kesinlikle sağlamaktadır [7]. Sığ su denklemlerinde deniz derinliği ekseninde değişen düşey hız değişimi olmadığı ve basınç gradiyentinin neredeyse hidrostatik koşullarda olduğu kabulü yapılır. Bu kabuller dikkate alınarak sığ su denklemleri süreklilik ve momentum denklemlerinin birlikte analizi ile Nami-Dance programında derive edilir [7]. Herbir rastgele deprem için parametreler belirlenmiş ve Nami-Dance programına manuel olarak girilmiştir. Nami Dance programı ile çalışma alanında oluşturulmuş örnek bir tsunami kaynağı Fotoğraf 3 'te gösterilmiştir.

Karanın iç kısımlarında güvenilir su basma seviyeleri hesaplayabilmek için batimetri ve kritik bölgelerin topoğrafik haritalarının çözünürlüğünün yüksek olması gerekmektedir. $\mathrm{Bu}$ tip yüksek çözünürlüklü haritaların elde edilmesi oldukça zor ve tsunami simülasyonları da bu çalışmadaki gibi büyük alanlarda çok uzun süreler almaktadır. Ayrıca bu çalışmanın amacı kritik bölgelerdeki bağıl sosyal risklerin belirlenmesidir. Bu açıdan, simülasyonlarda -50 m'ye yerleştirilmiş dijital ölçeklerden elde edilen verilerin Green eşitliği kullanılarak kıyıya taşınması büyük kolaylık sağlayamaktadır. Aynı yöntem ile tsunami dalgalarının kıyıya taşındığı ve güvenilir sonuçlar elde edilen çalışmalar da vardır [19-20]. Green eşitliği aşağıdaki şekilde ifade edilmektedir [21]: 


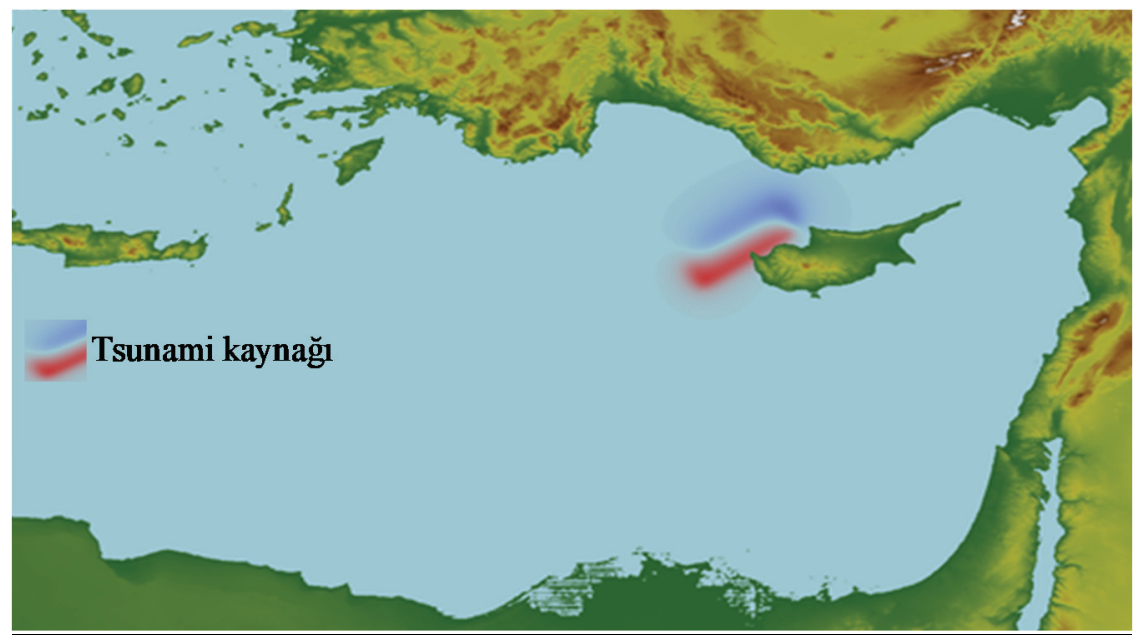

Fotoğraf 3 - Nami-Dance kullanılarak oluşturulmuş örnek tsunami kaynağ

$\frac{H_{1}}{H_{50}}=\left(\frac{d_{50}}{d_{1}}\right)^{\frac{1}{4}}$

burada $H_{50}$ ve $H_{1}$ sirasıly $50 \mathrm{~m}$ ve $1 \mathrm{~m}$ su derinliklerindeki tsunami dalga yüksekliklerini, $d_{50}$ ve $d_{1}$ sırasıyla $50 \mathrm{~m}$ ve $1 \mathrm{~m}$ su derinliklerini göstermektedir. Bu eşitlik ile her bir kritik bölge için $50 \mathrm{~m}$ su derinliğinde simülasyondan elde edilen tsunami dalga yüksekliği $1 \mathrm{~m}$ su derinliğinin bulunduğu noktalarda hesaplanmaktadır.

\subsection{Sosyal Risk Analizi}

Literatürde risk, bir olayın gerçekleşme olasılığı (beklenen değer) ile o olaya ait sonuçların (gerçekleşen değer) bir bileşimi olarak tanımlanır [22]. Riski bir eşitlik ile ifade etmek gerekirse:

Risk $=$ Olasılık $*$ Sonuç

bu çalışmada Sonuç tsunami sebebiyle su altında kalan bölgedeki sosyal etkileri ifade etmektedir. Olasılık ise ilgili olayın olma ihtimalini belirtmektedir.

$\mathrm{Bu}$ çalışmadaki sosyal risk hesaplarında sonuç, tsunami nedeniyle zarar gören insan sayısını (IS) ifade etmektedir. Bir insana zarar verebilecek tsunami dalga yükseliği literatür incelemelerine dayanarak 0.5 m olarak kabul edilmiştir [23,24,25]. Sosyal risk analizi için 3 aşamalı bir hesaplama yöntemi kullanılmıştır. Bu yöntemde, öncelikle Monte Carlo simulasyonlarından elde edilen rastgele deprem kaynağı verilerinin olasılıksal analizinden elde edilen aşılma ihtimali $(A I)$ değerleri ile tsunami simulasyonları sonucunda elde edilen su basma seviyeleri kullanılarak aşılma ihtimali $(A I)$ - su basma seviyesi (SS) eğrileri hazırlanır. Aşılma ihtimalinde dikkate alınan su basma seviyesi, bir insanı fiziksel olarak 
etkilecebilecek minimum su derinliği $(0.5 \mathrm{~m})$ olarak dikkate alınır [23,24,25]. Daha sonra literatüden elde edilen veriler ile tsunami simulasyonlarında elde edilen su basma seviyeleri kullanılarak, her bir su basma seviyesine karşılık zarar göreceği öngörülen insan sayısı belirlenir. Bu sayede her bir su basma seviyesinde zarar göreceği hesaplanan insan sayısı eğrisi (IS-SS) belirlenir. Son olarak ilk iki eğrinin kombinasyonundan, verilerinin olasılıksal analizinden elde edilen aşılma ihtimaline karşılık gelen zarar gören insan sayısı eğrisi (IS-AI) çizilerek olasılıksal sosyal risk analizi için gerekli girdi elde edilir. Çizim 4'te sosyal risk hesabı için hazırlanmış 3 aşamalı hesaplama yöntemini gösteren örnek eğriler verilmiştir.
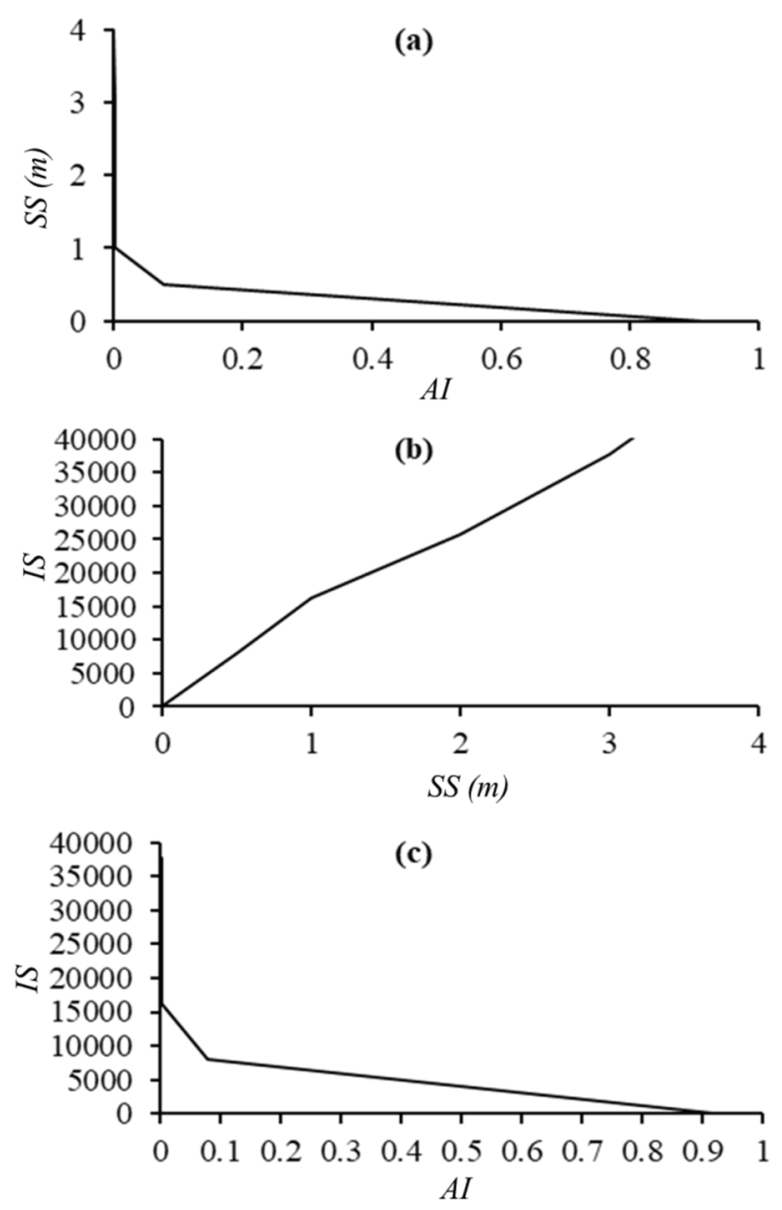

Çizim 4 - Sosyal risk hesabında kullanılan örnek (a) AI-SS, (b) IS-SS ve (c) IS-AI grafikleri

Doğal veya insan kaynaklı afetlerden dolayı oluşması muhtemel zararların risk analizi yapılırken daha güvenilir veri elde edebilmek için insanların zarar görebilirlik seviyelerinin $\left(C_{\text {zarar }}\right)$ belirlenmesi benimsenmiştir. İnsanların zarar görebilirlik seviyelerinin 
belirlenmesinde literatürde genellikle insanların gelir seviyeleri $\left(I_{\text {gelir }}\right)$, eğitim seviyeleri $\left(I_{\text {eğitim }}\right)$, sağlık seviyeleri $\left(I_{\text {sağ llk }}\right)$ ve altyapı hizmetlerine erişìm $\left(I_{\text {altyapl }}\right)$ gibi yaşam endeksi değerleri indikatörler olarak kullanılmaktadır [13, 26-29]. Bu çalışmada da insanların zarar görebilirlik seviyelerinin belirlenmesinde bu dört indikatörün normalize edilmiş değerleri kullanışmıştır. Normalizasyon, seçilen kritik bölgelerin bulundukları şehirlerin yaşam endeksi değerinin diğer iller arasında en yüksek değere sahip olan ilin yaşam endeksine bölünmesi ile elde edilir:

$$
\begin{aligned}
& N_{I_{\text {gelir }}}=\frac{I_{\text {gelir }_{i l}}}{I_{\text {gelir }_{\text {En yüksek }}}}, N_{I_{\text {eğ itim }}}=\frac{I_{\text {ĕ̆itim }} \text { il }}{I_{\text {eğitim }} \text { En yüksek }}, \\
& N_{I_{\text {să̆ llk }}}=\frac{I_{\text {să̆ } l l k_{i l}}}{I_{\text {sağ llk }_{\text {En yüksek }}}}, \quad N_{I_{\text {altyap }}}=\frac{I_{\text {altyap }_{\text {il }}}}{I_{\text {altyapl }_{\text {En yüksek }}}}
\end{aligned}
$$

burada $N_{I_{\text {gelir }}}$ normalize edilmiş gelir seviyesi , $N_{I_{\text {eğitim }}}$ normalize edilmiş eğitim seviyesi, $N_{I_{\text {sağllk }}}$ normalize edilmiş sağlık seviyeleri, ve $N_{I_{\text {altyap }}}$ normalize edilmiş altyapı hizmetlerine erişim, $I_{\text {gelir }}$ il seçilen kritik bölgelerin bulunduğu şehirlerdeki insanların gelir seviyeleri, $I_{e g ̆ i t i m}$ il seçilen kritik bölgelerin bulunduğu şehirlerdeki insanların eğitim seviyeleri, $I_{s_{a g ̆} l k_{i l}}$ seçilen kritik bölgelerin bulunduğu şehirlerdeki insanların sağlık seviyeleri, $I_{\text {altyap }_{i l}}$ ise seçilen kritik bölgelerin bulunduğu şehirlerdeki insanların altyapı hizmetlerine erişim oranıdır. $I_{\text {gelir }}$ En yüksek, $I_{\text {ĕ̆itim }}$ Enyüksek,$\quad I_{\text {sağllk }}$ En yüksek, ve

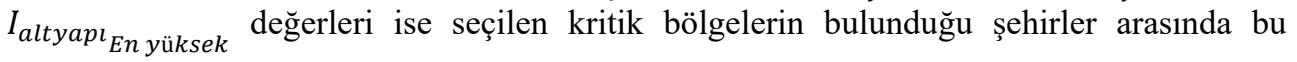
indekslerin en yüksek değerlerine sahip il verisidir. Belirtilen illerin ilgili indeksleri Çizelge 4 'te verilmiştir. Her bir indikatörün en yüksek değeri gri ile işaretlenmiştir. Bu çalışmada zarar görebilirlik, $C_{\text {zarar }}$ bu dört indikatör kullanılarak aşağıdaki şekilde hesaplanmıştır:

$C_{\text {zarar }}=\frac{1}{\frac{1}{4}\left\{N_{I_{\text {gelir }}}+N_{I_{\text {ĕgitim }}}+N_{I_{\text {să̆llk }}}+N_{I_{\text {altyapl }}}\right\}}$

Çizelge 4 - Kritik bölgelerin bulunduğu şehirlerin zarar görebilirlik indikatörleri [29]

\begin{tabular}{lcccc}
\hline & \multicolumn{4}{c}{ Zarar görebilirlik indikatörleri } \\
\cline { 2 - 5 } Şehir & $I_{\text {gelir }}$ & $I_{\text {eğitim }}$ & $I_{\text {să̆llk }}$ & $I_{\text {altyap }}$ \\
\hline Adana & 0.3506 & 0.4477 & 0.5039 & 0.6784 \\
Antalya & 0.5838 & 0.6437 & 0.6249 & 0.6237 \\
Hatay & 0.3536 & 0.5254 & 0.5046 & 0.4223 \\
Mersin & 0.2885 & 0.6418 & 0.5062 & 0.5253 \\
Muğla & 0.5527 & 0.6139 & 0.7042 & 0.5301 \\
\hline
\end{tabular}


Bu çalışmada Türkiye'nin Doğu Akdeniz sahillerinden seçilen kritik bölgelerin bulundukları iller için hesaplanan $C_{\text {zarar }}$ değerleri Çizelge 5 'te verilmiştir.

\begin{tabular}{|c|c|}
\hline Şehir & $C_{\text {zarar }}$ \\
\hline Adana & 1.33 \\
\hline Antalya & 1.05 \\
\hline Hatay & 1.45 \\
\hline Mersin & 1.34 \\
\hline Muğla & 1.09 \\
\hline
\end{tabular}

Sosyal risk hesabında insanların kritik bölgenin tamamında homojen bir şekilde dağılım gösterdiği varsayılmaktadır. Tsunami dalga yüksekliğinin $0.50 \mathrm{~m}$ ve daha yüksek olarak gözlemlendiği bölgeler sosyal risk hesabına dahil edilmiştir. Her bir kritik bölge için o bölgeye ait $I S-A I$ eğrisinin altında kalan alanın integrasyonu ile sosyal risk hesaplanmaktadır. Sosyal risk eşitliği:

Risk $_{\text {sosyal }}\left\{\begin{array}{lll}0 & S S<0.5 \mathrm{~m} & \text { ise } \\ \sum \Delta P \overline{S Z} & S S \geq 0.5 \mathrm{~m} & \text { ise }\end{array}\right.$

burada $\Delta P=\left|P_{j}-P_{j-1}\right| j$ ve $j-1$ olarak ifade edilen iki $A I$ arasında kalan olasılık, $\overline{S Z}=$ $\frac{1}{2}\left[S Z_{j}+S Z_{j-1}\right]$ ise bu iki $A I$ arasındaki sosyal zarar miktarını ifade etmektedir. Her bir $S S$ aralığı için $S Z_{S S}$ değeri ise;

$S Z_{S S}=\left\{\begin{array}{lcc}0 & S S<0.5 \mathrm{~m} & \text { ise } \\ \sum n y A_{S S} I S_{S S} C_{\text {zarar }} & S S \geq 0.5 \mathrm{~m} & \text { ise }\end{array}\right.$

burada $C_{\text {zarar }}$ zarar görebilirlik katsayısını, ny kritik bölgedeki nüfus yoğunluğunu, ve $A_{S S}$ ise su basma seviyesinin altında kalan alanı ifade etmektedir. Kritik bölgede $0.50 \mathrm{~m}$ su basma seviyesinin altında kalan alanlardaki sosyal risk 0 olarak kabul edilmektedir.

\section{BULGULAR VE TARTIŞMALAR}

Bu çalışmada Türkiye'nin Doğu Akdeniz kıyılarında bulunan yerleşim yerleri, tarım alanları, limanları ve havaalanlarının tarihte Doğu Akdeniz'de görülmüş 365 Girit, 1222 Paphos ve 1303 Girit depremleri dikkate alınarak olası bir tsunamijenik depremde karşılaşabileceği sosyal risk seviyeleri hesaplanmıştır. Monte Carlo yöntemi ile her bir tarihsel deprem için 1000 'er adet rastgele deprem kaynağı oluşturulmuş ve tsunami simulasyonları yapılarak tsunami dalga yükseklikleri belirlenmiştir. Deprem simülasyonlarından elde edilen verilere göre 3 tarihsel deprem lokasyonunda oluşturulan rastgele depremlerden elde edilen $S S$ değerleri önemli turistik bölgelerin ikisi olan Antalya Konyaaltı plajı ve Fethiye şehir 
merkezi için Çizim 5 'te verilmiştir. Literatürde tsunami oluşturabilecek deprem büyüklüğü, $M_{w}$ minimum 6.5 verildiği için grafiklerde bu büyüklükten itibaren elde edilen $S S$ değerleri gösterilmiştir [30]. Diğer seçilen kritik bölgelerdeki her bir deprem için maksimum su basma seviyeleri Çizelge 6'da verilmiştir.
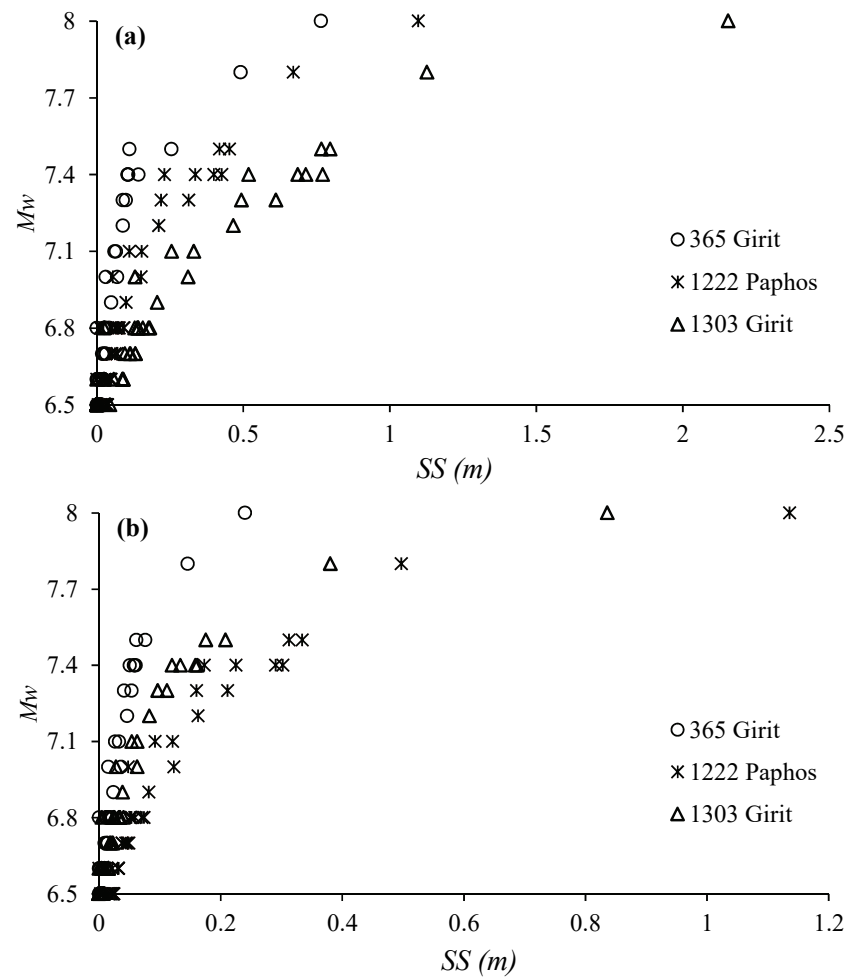

Çizim 5 - (a) Fethiye Şehir merkezi ve (b) Konyaaltı plajı için simülasyonlardan elde edilen olasılıksal $M_{w}$-SS değerleri

Çizelge 6 - Seçilen kritik bölgelerdeki her bir deprem için maksimum SS değerleri

\begin{tabular}{ccccc}
\hline \multirow{2}{*}{ Kritik Bölge } & \multirow{2}{*}{ Il } & \multicolumn{3}{c}{ Depremin maksimum dalga yüksekliği (m) } \\
\cline { 3 - 5 } & & 365 Girit & 1222 Paphos & 1303 Girit \\
\hline Akdeniz Tatil Köyleri & Antalya & 0.25 & 1.04 & 0.44 \\
Alanya Kıyı Şeridi & Antalya & 0.15 & 1.66 & 1.13 \\
Anamur Kıyı Şeridi & Mersin & 0.20 & 1.70 & 0.63 \\
Antalya Konyaalti & Antalya & 0.24 & 1.14 & 0.84 \\
Arsuz Tatil Köyleri & Hatay & 0.10 & 0.58 & 0.28 \\
Belek Tatil Köyleri & Antalya & 0.21 & 0.93 & 0.55 \\
\hline
\end{tabular}


Çizelge 7 - Seçilen kritik bölgelerdeki her bir deprem için maksimum SS değerleri (devam)

\begin{tabular}{|c|c|c|c|c|}
\hline \multirow{2}{*}{ Kritik Bölge } & \multirow{2}{*}{ İl } & \multicolumn{3}{|c|}{ Depremin maksimum dalga yüksekliği (m) } \\
\hline & & 365 Girit & 1222 Paphos & 1303 Girit \\
\hline Dalaman Şehir Merkezi & Muğla & 0.33 & 0.68 & 1.88 \\
\hline Demre Şehir Merkezi & Antalya & 0.15 & 0.63 & 0.86 \\
\hline Erdemli Şehir Merkezi & Mersin & 0.23 & 1.12 & 0.41 \\
\hline Fethiye Şehir Merkezi & Muğla & 0.77 & 1.10 & 2.15 \\
\hline Finike Şehir Merkezi & Antalya & 0.34 & 0.65 & 1.12 \\
\hline İskenderun Şehir Merkezi & Hatay & 0.11 & 0.64 & 0.28 \\
\hline Kazanlı Şehir Merkezi & Mersin & 0.12 & 0.85 & 0.30 \\
\hline Kemer Şehir Merkezi & Antalya & 0.24 & 0.99 & 0.68 \\
\hline Kızkalesi Tatil Köyleri & Mersin & 0.15 & 1.18 & 0.44 \\
\hline Manavgat Kıyı Şeridi & Antalya & 0.12 & 0.93 & 0.62 \\
\hline Mersin Şehir Merkezi & Mersin & 0.12 & 0.85 & 0.30 \\
\hline Samandağ Şehir Merkezi & Hatay & 0.19 & 0.82 & 0.34 \\
\hline Sarıseki Şehir Merkezi & Hatay & 0.12 & 0.62 & 0.29 \\
\hline Susanoğlu Tatil Köyleri & Mersin & 0.13 & 0.98 & 0.36 \\
\hline Taşucu Şehir Merkezi & Mersin & 0.14 & 1.27 & 0.49 \\
\hline Türkler Tatil Köyleri & Antalya & 0.19 & 1.49 & 0.78 \\
\hline Yemişkumu Tatil Köyleri & Mersin & 0.14 & 1.30 & 0.45 \\
\hline Dalaman Havaalanı & Muğla & 0.33 & 0.68 & 1.88 \\
\hline İskenderun Limanı & Hatay & 0.11 & 0.64 & 0.28 \\
\hline Mersin Limanı & Mersin & 0.12 & 0.85 & 0.30 \\
\hline MMK Metalurji Limanı & Hatay & 0.10 & 0.74 & 0.32 \\
\hline Akdeniz Limanı & Antalya & 0.24 & 1.05 & 0.74 \\
\hline Tirtar Yat Limanı & Mersin & 0.15 & 1.31 & 0.44 \\
\hline Çukurova Tarım Alanı & Adana & 0.10 & 0.94 & 0.33 \\
\hline Dalaman Tarım Alanı & Muğla & 0.33 & 0.68 & 1.88 \\
\hline Samandag Tarım Alanı & Hatay & 0.19 & 0.82 & 0.34 \\
\hline
\end{tabular}

Olasılıksal hesaplamalardan elde edilen verilere göre bazı kritik bölgeler için tsunami dalga yükseklikleri 2 metrenin üzerine çıkmaktadır. Fakat neredeyse seçilen tüm kritik bölgeler için 1222 Paphos depremi verileri ve lokasyonu kullanılarak yapılan olasılıksal deprem riski analizi bu tarihsel depremler arasında en yüksek tsunami dalga boylarını vermektedir. Bunun nedeni olarak 1222 Paphos depreminin lokasyonunun Doğu Akdeniz'in neredeyse merkezinde yer alması gösterilebilir. 
Türkiye'nin Doğu Akdeniz kıyıları boyunca seçilen kritik bölgelerin sosyal risk hesapları kritik bölgeler arasındaki sosyal risk farkının ortaya daha rahat konulabilmesi açısından bağıl risk şeklinde verilmiştir. Bağıl risk her bir risk altındaki bölgenin sosyal riskinin hesaplanan maksimum sosyal riske bölünmesi ile elde edilir (Eş.11). Bağıl risk seviyeleri 5 farklı seviyeye ayrılıp, her bir risk seviyesi Çizelge 7'de farklı bir renk ile gösterilmiştir. Her bir kritik bölge için 365 Girit, 1222 Paphos ve 1303 Girit depremleri referans alınarak hesaplanan bağıl sosyal risk seviyeleri Çizelge 8'de verilmiştir ve Çizelge 7'de sunulan sinıflandırmaya göre renklendirilmiştir.

$N_{-} R_{i s} k_{\text {Sosyal }}=\frac{\text { Risk }_{\text {Sosyal }}}{\text { Risk }_{\text {Sosyal,maks }}}$

\section{Çizelge 8 - Risk seviyeleri}

\begin{tabular}{|ccc|}
\hline $0.75 \leq$ & Çok Yüksek Risk & $\leq 1$ \\
$0.50 \leq$ & Yüksek Risk & $<0.75$ \\
$0.25 \leq$ & Orta Seviyeli Risk & $<0.50$ \\
$0<$ & Düşük Risk & $<0.25$ \\
$0=$ & Risk Yok & \\
\hline
\end{tabular}

Çizelge 9 - 365 Girit, 1222 Paphos ve 1303 Girit depremleri referans alınarak hesaplanan bağll sosyal risk seviyeleri

\begin{tabular}{ccccc}
\hline \multirow{2}{*}{ Kritik Bölge } & \multirow{\text{İl}}{}{} & \multicolumn{3}{c}{ Bağıl Sosyal Risk Seviyeleri } \\
\cline { 3 - 5 } & & 0.39 & 0.43 & 0.38 \\
\hline Akdeniz Tatil Köyleri & & 1.00 & 1.00 & 1.00 \\
Alanya Kıyı Şeridi & Antalya & 122 Paphos & 1303 Girit \\
Anamur Kıyı Şeridi & Antalya & 0.00 & 0.00 & 0.00 \\
Antalya Konyaalti & Mersin & 0.05 & 0.05 & 0.05 \\
Arsuz Tatil Köyleri & Antalya & 0.00 & 0.00 & 0.00 \\
Belek Tatil Köyleri & Hatay & 0.60 & 0.59 & 0.58 \\
Dalaman Şehir Merkezi & Antalya & 0.00 & 0.00 & 0.00 \\
Demre Şehir Merkezi & Muğla & 0.00 & 0.00 & 0.00 \\
Erdemli Şehir Merkezi & Antalya & 0.01 & 0.01 & 0.01 \\
Fethiye Şehir Merkezi & Mersin & 0.18 & 0.18 & 0.23 \\
Finike Şehir Merkezi & Muğla & 0.02 & 0.02 & 0.02 \\
İskenderun Şehir Merkezi & Antalya & 0.01 & 0.03 & 0.03 \\
Kazanlı Şehir Merkezi & Hatay & 0.01 & 0.01 & 0.01 \\
\hline
\end{tabular}


Çizelge 10 - 365 Girit, 1222 Paphos ve 1303 Girit depremleri referans alınarak hesaplanan bağll sosyal risk seviyeleri (devam)

\begin{tabular}{ccccc}
\hline \multirow{2}{*}{ Kritik Bölge } & \multirow{1}{*}{} & \multicolumn{3}{c}{ Bağıl Sosyal Risk Seviyeleri } \\
\cline { 3 - 5 } & & 365 Girit & 1222 Paphos & 1303 Girit \\
\hline Kemer Şehir Merkezi & Mersin & 0.10 & 0.10 & 0.10 \\
Kızkalesi Tatil Köyleri & Antalya & 0.00 & 0.00 & 0.00 \\
Manavgat Kıyı Şeridi & Mersin & 0.20 & 0.20 & 0.20 \\
Mersin Şehir Merkezi & Antalya & 0.00 & 0.00 & 0.00 \\
Samandağ Şehir Merkezi & Mersin & 0.00 & 0.00 & 0.00 \\
Sarıseki Şehir Merkezi & Hatay & 0.00 & 0.00 & 0.00 \\
Susanoğlu Tatil Köyleri & Hatay & 0.36 & 0.35 & 0.34 \\
Taşucu Şehir Merkezi & Mersin & 0.00 & 0.00 & 0.00 \\
Türkler Tatil Köyleri & Mersin & 0.08 & 0.09 & 0.08 \\
Yemişkumu Tatil Köyleri & Antalya & 0.00 & 0.00 & 0.00 \\
Dalaman Havaalanı & Mersin & 0.08 & 0.07 & 0.08 \\
İskenderun Limanı & Muğla & 0.00 & 0.00 & 0.00 \\
Mersin Limanı & Hatay & 0.00 & 0.00 & 0.00 \\
MMK Metalurji Limanı & Mersin & 0.00 & 0.00 & 0.00 \\
Akdeniz Limanı & Hatay & 0.17 & 0.18 & 0.17 \\
Tırtar Yat Limanı & Antalya & 0.00 & 0.00 & 0.00 \\
Çukurova Tarım Alanı & Mersin & 0.78 & 0.81 & 0.77 \\
Dalaman Tarım Alanı & Adana & 0.08 & 0.08 & 0.09 \\
Samandag Tarım Alanı & Muğla & 0.01 & 0.01 & 0.01 \\
\hline & & & &
\end{tabular}

365 Girit, 1222 Paphos ve 1303 Girit depremleri referans alınarak hesaplanan bağıl sosyal risk hesaplamalarına göre Alanya Kıyı Şeridi ve Çukurova Tarım Alanı "Çok Yüksek Risk" seviyesinde çıkmıştır. Sosyal riskin bu bölgelerdeki yüksek değeri, yüksek nüfus yoğunluğunun bir fonksiyonu olarak açıklanabilir. Ayrıca Belek bölgesindeki tatil köylerinin bağıl sosyal riski "Yüksek Risk", Akdeniz ve Susanoğlu bölgelerinde bulunan tatil köylerinin sosyal riski de "Orta Seviyeli Risk" çıkmıştır. Her ne kadar farklı depremler için farklı tsunami dalga yükseklikleri elde edilmiş olsa da, düşük seviyelerde oluşan tsunami dalga yüksekliklerinin sayıca fazla olması, bağıl sosyal risk hesaplarında benzer risk seviyelerinin elde edilmesine neden olmuştur. Diğer bölgelerin düşük nüfus yoğunluğu ve 0.50 m'yi aşmayan tsunami dalgalarından dolayı etkilenen insan sayısının azlığından bağıl sosyal risk seviyeleri "Düşük" ve "Risk Yok" şeklinde belirlenmiştir. 


\section{SONUÇLAR}

Bu çalışmada Türkiye'nin Doğu Akdeniz sahil şeridinde yerleşim yerleri, tarım alanları, limanlar ve havaalanlarından oluşan 32 kritik bölge için olası bir tsunami tehlikesi durumunda sosyal risk seviyelerinin ne olabileceği hesaplanmıştır. Bağımsız deprem parameteleri için Monte Carlo yöntemi kullanılarak rastgele deprem kaynağı verisi oluşturulmuş, bağımlı parametreler için de Akdeniz'de bulunan Helenik ve Kıbrıs fay hatları üzerinde tarihte yaşanmış 365 Girit, 1222 Paphos ve 1303 Girit depremlerinin bağımlı parametreleri (doğrultu, eğim ve dalma açıları, enlem ve boylam) dikkate alınarak analizler yapılmıştır.

Elde edilen bulgular, her 3 deprem için de seçilen kritik bölgelerin 18'inde çeşitli seviyelerde sosyal riskin bulunduğunu, 14'ünde ise herhangi bir sosyal riskin bulunmadığını ortaya koymaktadır. Fakat burada asıl dikkat edilmesi gereken nokta seçilen kritik bölgelerin sosyal risk seviyelerinin her 3 deprem için de benzerlik göstermesidir. Her ne kadar tsunami dalga yükseklikleri seçilen bölgelerde farklılık gösterse de bu bölgelerin birbirinden farklı olan nüfus yoğunlukları, topoğrafyası ve etkilenen alanın büyüklüğü benzer risk seviyelerinin elde edilmesine sebep olarak gösterilebilir.

Seçilen bölgelerin bir kısmı turistik alanlar olmasına rağmen, aylık nüfus yoğunluğu verisini elde etmek mümkün değildir. Bunun yanı sıra, simüle edilen depremlerin oluşma zamanları için bir tahmin yapılmamıştır. Dolayısıyla bu çalışmada ortaya konulan sosyal risk analizleri, ilgili bölgelerin, mevsimsel farklılıklar ihmal edilerek elde edilen nüfus yoğunluğu verileri ve herhangi bir zamanda oluşabilecek depremler dikkate alınarak hesaplanmıştır. Turistik bir sezonda yaşanabilecek bir tsunami tehlikesinin seçilen bölgelerde bu çalışmada verilen sosyal risk seviyelerinden çok daha büyük bir risk oluşturması kaçınılmazdır. Ortaya konulan verilen ve her bir bölgede görülebilecek olası tsunami dalga yükseklikleri yerel otoritelerin gerekli tedbirleri almasında faydalı olabilecek niteliktedir. Bu çalışmanın amacı kriz yönetiminden ziyade risk yönetimi konusunda bilimsel çevrelere 1şık tutabilmektir.

\section{Teşekkür}

Yazarlar değerli katkılarından ve önerilerinden dolayı Prof. Dr. Mustafa M. Aral' a teşekkür ederler.

\section{Kaynaklar}

[1] Ring of Fire. https://www.google.com/earth/ Erişim tarihi: Ağustos 20, 2020.

[2] Twiss. R. J., Moores. E. M., Structural Geology, WH Freeman and Company, New York, A.B.D., 2007.

[3] Google Earth Pro v7.3.3.7786 (2020) http://www.earth.google.com Erişim tarihi Ekim 20,2020

[4] International Tsunami Information Center. How do earthquakes generate tsunamis? http://www.ioctsunami.org/index.php?option $=$ com_oe\&task=viewDocumentRecord\&docID $=26561$ Yayın tarihi Haziran 30, 2019. Erişim tarihi Ağustos 20, 2020. 
[5] Altinok, Y., Ersoy, Ş., Tsunamis Observed on and Near the Turkish Coast. In: Papadopoulos G.A., Murty T., Venkatesh S., Blong R. (eds) Natural Hazards, Springer, Dordrecht, 2000. https://doi.org/10.1007/978-94-017-2386-2_5

[6] Papadopoulos, G. A., Daskalaki, E., Fokaefs A., Giraleas N., Tsunami hazard in the Eastern Mediterranean Sea: strong earthquakes and tsunamis in the west Hellenic arc and trench system. Journal of Earthquake and Tsunami, 4 (03), 145-179, 2010.

[7] Yalciner, A. C., Pelinovsky, E., Zaytsev, A., Kurkin, A., Ozer, C., Karakus, H., Nami Dance Manual. Middle East Technical University, Civil Engineering Department, Ocean Engineering Research Center, Ankara, 2006.

[8] Earthquake Glossary. https://earthquake.usgs.gov/learn/glossary/ Erişim tarihi: Ağustos 20, 2020.

[9] Altinok, Y., Tinti, S., Alpar, B., Yalciner, A. C., Ersoy, Ş., Bortolucci, E., Armigliato, A., The tsunami of August 17, 1999 in Izmit bay, Turkey. Natural Hazards, 24(2), 133146, 2001.

[10] Yolsal, S., Taymaz, T., Yalciner, A. C., Understanding tsunamis, potential source regions and tsunami-prone mechanisms in the Eastern Mediterranean. Geological Society, London, Special Publications, 291(1), 201-230, 2007.

[11] Yolsal-Çevikbilen, S., Taymaz, T., Earthquake source parameters along the Hellenic subduction zone and numerical simulations of historical tsunamis in the Eastern Mediterranean. Tectonophysics, 536, 61-100, 2012.

[12] TUIK.., Yıllara Göre İllerin Yıllık Nüfus Artış Hızı ve Nüfus Yoğunluğu, http://tuik.gov.tr/PreTablo.do?alt_id=1059 Erişim tarihi Eylül 10, 2020.

[13] Yavuz, C., Kentel, E., Aral, M. M., Tsunami Risk Assessment: Economic, Environmental and Social Dimensions. Natural Hazards, 2020. DOI: 10.1007/s11069020-04226-y

[14] Hanks, T. C., Kanamori, H., A moment-magnitude scale. J. Geophys. Res. 84, 2348$2350,1979$.

[15] Wells, D. L., Coppersmith, K. J., New empirical relationships among magnitude, rupture length, rupture width, rupture area, and surface displacement. Bulletin of the seismological Society of America, 84(4), 974-1002, 1994.

[16] Papazachos, B. C., Scordilis, E. M., Panagiotopoulos, D. G., Papazachos, C. B., Karakaisis G. F., Global Relations Between Seismic Fault Parameters and Moment Magnitude of Earthquakes. Bulletin of the Geological Society of Greece, 36, 2004.

[17] Blaser, L., Krüger, F., Ohrnberger, M., Scherbaum, F., Scaling relations of earthquake source parameter estimates with special focus on subduction environment. Bulletin of the Seismological Society of America, 100(6), 2914-2926, 2010.

[18] Goda, K., Yasuda, T., Mori, N., Maruyama, T., New scaling relationships of earthquake source parameters for stochastic tsunami simulation. Coastal Engineering Journal, 58(03), 1650010, 2016. 
[19] Løvholt, F., Glimsdal, S., Harbitz, C. B., Zamora, N., Nadim, F., Peduzzi, P., Smebye, H., Tsunami hazard and exposure on the global scale. Earth-Science Reviews, 110(14), 58-73, 2012.

[20] Løvholt, F., Glimsdal, S., Harbitz, C. B., Horspool, N., Smebye, H., De Bono, A., Nadim, F., Global tsunami hazard and exposure due to large co-seismic slip. International journal of disaster risk reduction, 10, 406-418, 2014.

[21] Synolakis, C. E., Green's law and the evolution of solitary waves. Physics of Fluids A: Fluid Dynamics, 3(3), 490-491, 1991.

[22] ISO 31010, 2009 Risk Management-Risk Assessment Techniques. CENELEC, Brussels, 2010.

[23] Abt, S.R., Wittler, R. J., Taylor, A., Predicting human instability in flood flows. In Hydraulic Engineering, 70-76, 1989.

[24] Endoh, K., Takahashi, S., Numerically modeling personnel danger on a promenade breakwater due to overtopping waves. Coastal Engineering, 1016-1029, 1994.

[25] Jonkman, S. N., Penning-Rowsell, E., Human instability in flood flows. JAWRA Journal of the American Water Resources Association, 44(5), 1208-1218, 2008.

[26] Tastan, B., Aydinoglu, A.C., Çoklu afet risk yönetiminde tehlike ve zarar görebilirlik belirlenmesi için gereksinim analizi. Marmara Coğrafya Dergisi, 31, 366-397, 2015.

[27] Cobanyilmaz, P., Yuksel, Ü.D., Kentlerin İklim Değişikliğinden Zarar Görebilirliğinin Belirlenmesi: Ankara Örneği. Journal of Natural \& Applied Sciences, 17(3), 2013.

[28] Ozceylan, D., Coskun, E. Türkiye'deki illerin sosyo-ekonomik gelişmişlik düzeyleri ve afetlerden sosyal ve ekonomik zarar görebilirlikleri arasındaki ilişki. Istanbul University Journal of the School of Business Administration, 41(1), 2012.

[29] Gelir, Eğitim, Sağlık ve Altyapı Değerleri, Web: https://data.tuik.gov.tr/Kategori/GetKategori?p=Gelir,-Yasam,-Tuketim-veYoksulluk-107

[30] USGS, What is it about an earthquake that causes a tsunami? https://www.usgs.gov/faqs/what-it-about-earthquake-causes-a-tsunami?qtnews_science_products=0\#qt-news_science_products Erişim tarihi Eylül 10, 2020. 